\title{
Scientific Research and the Imperial Conference, I930.
}

TTHE Imperial Conference of 1926 was dis1 tinguished by the lofty conceptions of the part which scientific research should take in the development of the British Commonwealth of Nations. Though it had been generally anticipated that economic questions would be the main issues at the Imperial Conference of 1930, many scientific workers and others who recognise the importance of science in economic affairs have been disappointed in what they consider the inadequate attention given to scientific research at this Conference. Fortunately, much more has been accomplished than has been reported in the public Press, and it is important that this fact should be realised and appreciated.

The two sections of the Conference most closely concerned with scientific matters were the Research Committee and the conference on standardisation, and it is noteworthy that the committee under Lord Parmoor provided the first occasion on which the responsible heads of the national industrial research bodies within the British Commonwealth of Nations met in a body to discuss their problems individually and collectively. Thus were met together Dr. F. E. Smith (Great Britain), Dr. H. M. Tory (Canada), Dr. A. C. D. Rivett (Australia), Dr. E. Marsden (New Zealand), Dr. P. J. du Toit (South Africa), Mr. J. Dulanty (Irish Free State), and Sir E. H. Pascoe (Director, Geological Survey of India), in addition to repre. sentatives from the British Ministry of Agriculture and Fisheries, Empire Marketing Board, and Imperial Institute.

Taking into account the existence of vigorous and well-organised national research bodies in Great Britain and the Dominions, it was not to be expected that the Research Committee would recommend the creation of still more forms of organisation. Its main task was to examine broadly the Imperial aspects of existing programmes of research, machinery for administration and consultation, training of research workers, and other questions; and to decide what further action could be taken to stimulate progress on the foundations laid down in previous Conferences and by direct communications.

In times of economic difficulty, efforts are made to lop off what are considered to be the less useful branches of activity, and Governments as well as commercial concerns are apt to regard research activities in this light. It was well, therefore, that the Research Committee, as one of its first recommendations, pointed out that the present severe economic depression should be regarded as a reason not for curtailment but for expansion of expenditure on research. In this connexion, it is only necessary to cite the valuable work in Australia on the influence of a supplementary protein diet in wool production, and in New Zealand on grassland problems, to realise the progress being made under the ægis of the respective national research bodies on problems of direct economic importance.

Agricultural research occupies a major position in the programmes of research in the Dominions, and it was natural that the committee should consider the results of the Imperial Agricultural Research Conference of 1927 and the work of the Imperial Agricultural Bureaux which were an outcome of that Conference. Both the details of the work being carried out by the bureaux and the manner of their establishment-financed from a common Empire fund and controlled by a council of nominees of the Governments of the British Commonwealth-were commended by the Research Committee. Following somewhat along the lines of the Imperial Institutes of Entomology and Mycology, these new bureaux deal with soils, animal nutrition, animal health, animal genetics, herbage and other farm crops, plant genetics, fruit production, and agricultural parasitology, and are gradually being recognised by research workers as trustworthy sources of information on the research aspects of the sciences concerned.

The research grants policy of the Empire Marketing Board was of special interest, since the Board is perhaps in the best position to draw together those interested in problems affecting the British Commonwealth as a whole, and to facilitate researches into these common problems by team work between two or more Dominions. Another phase of co-operative investigation which concerned the committee was the possibility of an interchange between the national research organisations of schemes of research, showing particularly the objectives and location of work of different lines of investigation. By this means, it is hoped that any unnecessary duplication will be reduced, and that economy of effort may be effected by definite collaboration in problems of mutual interest. This tendency to explore the possibilities of interDominion action was clearly shown in relation to projects for investigation into the mineral resources and wool production of the Empire. In both cases, the benefit of a common line of action was realised and steps were taken to define the objectives and general procedure.

While in Great Britain, the directors of the Dominion research organisations visited many of the laboratories of industrial research associations and made a careful examination of the work of the Department of Scientific and Industrial Research on such subjects as fuel, preservation and transport of food, building, radio, river pollution, and the national laboratories for physical and chemical research at Teddington. The discussion in com. mittee of research on these subjects was in many cases assisted by the presence of the directors of the laboratories concerned, and it was clear that the interchange of ideas by personal contact was likely to be reflected in the programmes of research both in Great Britain and in the Dominions. The deliberations on scientific research at the Imperial Conference of 1930 may indeed be summed up as a consolidation of the more spectacular achievements of the Conference of 1926.

Since most of the Dominion research organisations

No. 3188, VoL. 126] 
are closely concerned with the movement for industrial standardisation and simplification in their respective countries, the overseas delegates on research matters also attended the conference on standardisation. This conference dealt with the two main questions of fundamental standards and industrial standardisation.

The deliberations on fundamental standards of mass, length, etc., had as an objective the securing of uniform fundamental standards within the British Commonwealth of Nations, and it is pleasing to observe that a considerable measure of progress has been made towards this objective. Hitherto no guide to common procedure has been available, and there has been a tendency among the nations of the British Commonwealth for minute but serious errors to arise through lack of regular intercomparison of local standards, such as the pound, yard, $\mathrm{ohm}$, volt, etc. The conference, however, after recommending that there should be uniformity between the standards for all units of measurement of common use in the British Commonwealth of Nations, clearly indicated the procedure by which that uniformity may be established and maintained. Briefly, this involves a periodic reverification of the
Dominion reference standards for each primary unit with the corresponding standards in Great Britain.

The position of industrial standardisation within the British Commonwealth was a much more involved question than that of fundamental standards, since the issues at stake are closely related to the complex economic and political affairs of the Commonwealth.

At this, the first Imperial Conference on the subject, the oral exchange of views was valuable in showing the present position of industrial standardisation in each part of the Commonwealth and the directions in which the movement was spreading. Though considerable attention was given to such questions as uniformity of industrial specifications within the Commonwealth, consultation and modification of draft specifications, adherence to standards, and the relation of Governments to the local standardisation authorities, it must be admitted that there is a great deal still to be done if the subtle but potentially great force of industrial standardisation and simplification is to exert its maximum influence on Imperial trade developments.
A. S. F.

\section{Obituary.}

\section{Mr. Emile Garcke.}

$\mathrm{M}^{\mathrm{R}}$ R. EMILE GARCKE, one of the pioneers of the electrical industry, died on Nov. 14, at the age of seventy-four years. He was born in Germany in 1856, and came to England when he was very young. He became naturalised in 1880 . In 1883 he was appointed secretary to the Brush Engineering Co., and four years later became the managing director. He was specially interested in the continental export trade of the company. In 1900 he began to study the question of industrial copartnership, and in 1926 he initiated the co-partnership scheme of the Brush Co., which is operating very successfully. He was chairman of the council of the Industrial Co-partnership Association.

Mr. Garcke founded the electrical section of the London Chamber of Commerce and became its chairman. He is, perhaps, best known in connexion with the work he did as a director of the British Electric Traction Co., which owns electric tramway systems all over the country. He founded and became chairman of the Tramways and Light Railways Association. His commercial interests were very widely spread, and his life was a very busy one, as he was prominently associated with the legislation, finance, promotion, and organisation of many electrical undertakings. He was a member of the Institution of Electrical Engineers for more than forty years, and recently presented a very interesting portrait of André Marie Ampère to the Institution. He was also a fellow of the Royal Statistical Society and was a member of the Institute of Actuaries. In 1896 he founded "Garcke's Manual of Electrical Undertakings", which was an immediate success. He was chairman of the Electrical Press, Ltd., which publishes several technical journals.

In private life, Mr. Garcke was of a lovable and retiring nature. He was intensely interested in philosophy and loved nothing better than to discuss it with his friends. In 1929 he published a book which he called "Individual Understanding, a Layman's Approach to Practical Philosophy". In this he discusses the whole philosophy of life. $\mathrm{He}$ is not afraid to lay his inmost thoughts bare when he thinks that by so doing he will help others. In his opinion, the waste of material and mental energy by the human race due to a lack of mutual confidence, sympathy, and veracity is lamentable. He strongly believed that Nature is not against us, but is on our side in beneficent partnership. For every man the outstanding problem is to make the best use of his limited freedom of choice. He leaves a widow and one son, Mr. Sidney Garcke, who is a well-known company director.

\section{WE regret to announce the following deaths:}

Prof. C. Eykman, professor of hygiene in the University of Utrecht, who shared the Nobel Prize for medicine for 1929 with Sir F. Gowland Hopkins for discoveries in connexion with vitamins, aged seventy-two years.

Dr. Nathaniel O. Howard, forest pathologist of the U.S. Department of Agriculture, stationed at Brown University, who was known for his studies of the fungous diseases of forest and woody ornamental plants, on Sept. 14, aged fifty years.

Prof. C. E. Moss, professor of botany in the University of the Witwatersrand, Johannesburg, on Nov. 11, aged fifty-eight years.

Capt. O. Sverdrup, commander of the Fram and a well-known arctic explorer, on Nov. 26, aged seventy-six years.

No. 3188 , VoL. 126] 